\title{
For Katie
}


Matthew C. Augustine - 9781526127037

Downloaded from manchesterhive.com at $04 / 26 / 2023$ 11:19:46AM 